\title{
NILAI TUKAR PETANI PROVINSI BALI TAHUN 2015-2017
}

\author{
Farmers Terms of Trade Bali Province
}

\author{
Evendi Akhmad
}

Badan Pusat Statitstik Provinsi Bali, Bali, Indonesia

Email: akhmadevendi@gmail.com

\begin{abstract}
Farming activity is determined by the sustainability and welfare of farmers in farming activities. Farmers Exchange Rate (NTP) is one tool to measure farmers' welfare. Increased farmer exchange rates will affect the sustainability of farmers to conduct farming activities to produce agricultural produce. This study entitled Farmers Trade Rate Bali Province 2015 - 2017. The purpose of this study is to analyze the dynamics of the exchange rate of farmers Bali Province and the factors that influence it. The farmer's exchange rate is derived from the comparison of farmer's price index (It) to the index paid by the farmer (Ib) expressed as a percentage. The calculation of NTP in this study uses the base year 2012. The analysis in this study using quantitative data, in the form of secondary data sourced from the Central Bureau of Statistics (BPS) of Bali Province. This study is detailed in sub-sectors. The scope of this research covers food crops sub-sector, horticulture sub-sector, people's plantation sub-sector, livestock sub-sector and fishery sub-sector. The results showed that in 2015 - 2017, the average of NTP Bali in the food crops subsector decreased by 1.89 percent and the average NTP reached 96.66 while the other NTP subsector was more than 100 (base year 2012). The average NTP of other sub-sectors covering the Horticulture sub-sector is 103.27, the people's plantation subsector is 102.73, the livestock sub-sector is 114.27, and the fishery sub-sector reaches 104.17. Meanwhile, if all NTP subsectors are combined with 105.03. Factors affecting the index received by farmers is the result of farming received by farmers directly. While the index factors paid by farmers include household consumption groups and group production costs and capital goods increase (BPPBM). The analysis results show the value of household consumption groups and BPPBM groups more than 100. By 2015 - 2016 percentage of components that experienced the highest increase of foodstuff components of 7.89 percent and the lowest transportation component of -3.59 percent. In 2016 2017 the highest component of finished food, beverages, cigarettes and tobacco was 6.76 percent and the lowest transportation component was 0.19 percent.
\end{abstract}

Keywords: farmer exchange rate, index received by farmers, index paid by farmers, welfare of farmers

\begin{abstract}
ABSTRAK
Kegiatan usahatani sangat ditentukan oleh keberlasungan dan kesejahteraan petani dalam berkegiatan usahatani. Nilai Tukar Petani (NTP) merupakan salah satu alat untuk mengukur tingkat kesejahteraan petani. Nilai tukar petani yang meningkat akan mempengaruhi keberlangsungan petani untuk melakukan kegiatan usahatani guna memproduksi hasil pertanian. Peneltian ini berjudul Nilai Tukar Petani Provinsi Bali 2015 - 2017. Tujuan penelitian ini adalah menganalisis dinamika nilai tukar petani Provinsi Bali dan faktor-faktor yang mempengaruhinya. Nilai tukar petani diperoleh dari perbandingan indeks harga yang diterima petani (It) terhadap indeks yang dibayar petani (Ib) yang dinyatakan dalam persentase. Penghitungan NTP dalam penelitian ini menggunakan tahun dasar 2012. Analisis dalam penelitian ini menggunakan data kuantitatif, berupa data sekunder yang bersumber dari Badan Pusat Statistik (BPS) Provinsi Bali.Penelitian ini secara rinci dijabarkan menurut subsektor. Cakupan penelitian ini meliputi subsektor tanaman pangan, subsektor hortikultura, subsektor perkebunan rakyat, subsektor peternakan dan subsektor perikanan. Hasil penelitian menunjukkan tahun 2015 - 2017 rata-rata NTP Bali pada subsektor tanaman pangan mengalami penurunan sebesar 1,89 persen dan rata-rata NTP mencapai 96,66 sedangkan NTP subsektor lain nilainya lebih dari 100 (tahun dasar 2012). Adapun rata-rata NTP subsektor lain yang meliputi subsektor Hortikultura sebesar 103,27, subsektor perkebunan rakyat sebesar 102,73, subsektor peternakan sebesar 114,27, dan subsektor perikanan mencapai 104,17. Sementara itu jika digabungkan NTP semua subsektor mencapai 105,03. Faktor yang mempengaruhi indeks yang diterima petani merupakan hasil usahatani yang diterima petani secara langsung. Sedangkan faktor indeks yang dibayar petani meliputi kelompok konsumsi rumah tangga dan kelompok biaya produksi dan penambahan barang modal (BPPBM). Hasil analisis terlihat nilai kelompok konsumsi rumah tangga dan kelompok BPPBM lebih dari 100. Secara persentase tahun 2015 - 2016 komponen yang mengalami kenaikan paling tinggi yakni komponen bahan makanan sebesar 7,89 persen dan yang paling rendah komponen transportasi sebesar $-3,59$ persen. Tahun $2016-2017$
\end{abstract}


yang paling tinggi komponen makanan jadi, minuman, rokok dan tembakau sebesar 6,76 persen dan yang paling rendah komponen transportasi sebesar 0,19 persen.

Kata kunci: nilai tukar petani, indeks yang diterima petani, indeks yang dibayar petani, kesejahteraan petani

\section{PENDAHULUAN}

Pada Tahun 2013 pemerintah melalui Badan Pusat Statistik melakukan pendataan Sensus Pertanian (ST2013) yang mencangkup enam sub sektor pertanian.Hasil Sensus Pertanian 2013 rumah tangga usaha pertanian pengguna lahan tercatatmendominasi rumah tangga usaha pertanian di Provinsi Bali. Dari sebanyak 408.233 rumah tangga usaha pertanian di Provinsi Bali, sebesar 99 persen merupakan rumah tangga usaha pertanian pengguna lahan (404.507 rumah tangga). Sedangkan rumah tangga usaha pertanian bukan pengguna lahan hanya sebesar 1 persen atau sebanyak 3.726 rumah tangga.Rumah tangga pertanian pengguna lahan dapat digolongkan ke dalam dua kelompok besar, yaitu rumah tangga petani gurem (rumah tangga usaha pertanian yang menguasai kurang dari $5.000 \mathrm{~m} 2$ lahan) dan rumah tangga petani non gurem (rumah tangga usaha pertanian yang menguasai lebih dari atau sama dengan $5.000 \mathrm{~m} 2$ lahan). Hasil ST2013 menunjukkan bahwa rumah tangga usaha pertanian pengguna lahan masih didominasi oleh rumah tangga petani gurem. Sebanyak 64 persen dari rumah tangga pertanian pengguna lahan di Provinsi Bali, merupakan rumah tangga petani gurem(257.181 rumah tangga). Sedangkan rumah tangga petani non gurem tercatat sebesar 36 persen atau sebanyak 147.326 rumah tangga. (BPSProvinsi Bali, 2013). Menurut Dinas Pertanian Tanaman Pangan Provinsi Bali luas lahan pertanian di Bali pada tahun 2015 mencapai 353.802 Ha atau 62,77 persen dari total luas wilayah Provinsi Bali. Aktivitas sektor pertanian sebagian besar dilakukan di wilayah perdesaan dan didominasi oleh petani dengan kegiatan utama usahatani budidaya (on farm). Kondisi demikian kiranya menjadi hal yang relevan dan strategis untuk diupayakan pembangunan dalam rangka peningkatan pendapatan petani dengan tujuan meningkatkan kesejahteraan petani.

Belakangan ini pelaksanaan pembangunan pertanian telah berjalan dan banyak keberhasilan yang tercapai seperti, peningkatan hasil produksi, pembangunan sarana prasarana pertanian. Akan tetapi berbicara tentang sektor pertanian, kiranya tidak hanya membicarakan tentang kuantitas dan kualitas produksi, kemampuan dalam pembentukan nilai tambah maupun kemampuan dalam penyerapan tenaga kerja. Faktor kesejahteraan petani kiranya juga ikut diperhatikan. Tingkat kesejahteraan rumah tangga erat kaitannya dengan tingkat kemiskinan. Tingkat kemiskinan merupakan indikator yang dapat menggambarkan taraf kesejahteraan kehidupan masyarakat secara umum (BPS Provinsi Bali, 2017). Kemiskinan dan kesenjangan sosial merupakan permasalahan yang banyak dihadapi oleh negara-negara berkembang termasuk Indonesia. Sektor pertanian yang identik dengan daerah pedesaan, menghadapi masalah kemiskinan. Kondisi tingkat kesejahteraan masyarakat pedesaan dengan mata pencarian utama disektor pertanian sebagian besar kiranya masih dibawah ratarata pendapatan nasional.

BPS Provinsi Bali mencatat tingkat kemiskinan Bali di perdesaan pada September 2017 mencapai 5,42 persen atau sekitar 80,4 ribu orang. Berbagai upaya telah dilakukan pemerintah daerah dalam rangka meningkatkan kesejahteraan petani, baik dari sisi peningkatan nilai poduksi maupun penyedian sarana dan prasana produksi. Mengingat dominasi petani gurem yang rata-rata tinggal di wilayah perdesaan.

Dengan adanya pembangunan yang mengarah pada perbaikan kesejahteraan petani, maka diperlukan suatu alat ukur untuk menilai perkembangan tingkat kesejahteraan petani tersebut. Indikator yang sering digunakan untuk mengukur dan menggambarkan kesejahteraan petani adalah Nilai Tukar Petani (NTP). NTP merupakan perbandingan antara indeks harga yang diterima oleh petani terhadap indeks harga yang harus dibayar oleh petani. NTP juga menggambarkan nilai tukar antara produk pertanian yang dihasilkan oleh petani terhadap barang dan jasa yang diperlukan oleh petani untuk konsumsi rumah tangganya maupun untuk biaya produksi produk pertanin. Semakin tinggi nilai NTP maka semakin kuat daya beli petani dan semakin tinggi tingkat kesejahteraannya. Salah satu unsur kesejahteraan petani adalah kemampuan daya beli pendapatan petani untuk memenuhi kebutuhan pengeluaran rumah tangga tani. Peningkatan kesejahteraan dapat diukur dari peningkatan daya beli pendapatan untuk memenuhi pengeluarannya tersebut. Semakin tinggi daya beli pendapatan petani terhadap kebutuhan konsumsi maka semakin tinggi nilai tukar petani dan berarti secara relatih lebih sejahtera. Nilai tukar petani berkaitan dengan kekuatan relative daya beli komoditas hasil pertanian yang dihasilkan atau dijual petani dengan barang dan jasa yang dibeli atau dikonsumsi petani.

Nilai tukar petani disamping menggambarkan kekuatan daya beli komoditas yang diusahakan juga berkaitan dengan perilaku ekonomi rumah tangga, karena proses pengambilan keputusan rumah tangga untuk memproduksi, membelanjakan dan mengkonsumsi suatu barang merupakan bagian dari perilaku ekonomi rumah tangga. Nilai tukar petani yang tinggi akan mendorong kegairahan petani dalam berusahatani (Nurasa dan Rahmat, 2013). Tulisan ini akan mengalisis dinamika nilai tukar petani Provinsi Bali menurut subsektor dan faktor-faktor yang mempengaruhinya. 


\section{METODE PENELITIAN}

\section{Nilai Tukar Petani (NTP)}

NTP (Farmers Term of Trade) merupakan salah satu indikator untuk melihat tingkat kemampuan atau daya beli petani di perdesaan. NTP juga menunjukkan daya tukar (term of trade) dari produk pertanian terhadap barang dan jasa yang diperlukan petani untuk konsumsi rumahtangganya maupun untuk biaya produksi produk pertanian. Peningkatan kesejahteraan dapat diukur dari peningkatan daya beli pendatapan untuk memenuhi pengeluarannya tersebut. Semakin tinggi daya beli petani terhadap kebutuhan konsumsi maka semakin tinggi nilai tukar petani dan berarti secara relative lebih sejahtera. Menurut Simatupang, et al. (2007), bahwa penanda kesejahteraan yang unik bagi rumah tangga tani praktis tidak ada, sehingga NTP menjadi pilihan satu-satunya bagi pengamat pembangunan pertanian.BPS merumuskan Nilai Tukar Petani (NTP) diperoleh dari perbandingan indeks harga yang diterima petani (It) terhadap indeks harga yang dibayar petani (Ib) yang dinyatakan dalam persentase. Indeks harga yang diterima petani (It) didefinisikan sebagai indeks harga yang menunjukkan perkembangan harga produsen atas hasil prouksi petani. Sedangkan indeks harga yang dibayar petani (Ib) didefinisikan sebagai indeks harga yang menunjukkan perkembangan haga kebutuhan rumah tangga petani, baik untuk konsumsi rumah tangga maupun proses produksi pertanian. Semakin tinggi NTP, secara relatif semakin kuat pula tingkat kemampuan/daya beli petani. Menurut BPS (2014) secara matematis NTP dapat diformulasikan sebagai berikut.

$$
\begin{array}{ll}
\text { Rumus: } & N T P=\frac{I_{t}}{I_{b}} \times 100 \% \\
\text { NTP } & \text { : Nilai Tukar Petani } \\
\text { It } & \text { : Indeks harga yang diterima petani } \\
\text { Ib } & \text { : Indeks harga yang dibayar petani }
\end{array}
$$

BPS(2014) mendevinisikan dan memberi arti NTP sebagai berikut:

a. Nilai NTP > 100 diinterpretasikan petani mengalami surplus. Harga produksinya naik lebih besar dari kenaikan harga konsumsi dan biaya produksi. Pendapatan petani naik lebih besar dari pengeluarannya, dengan demikian tingkat kesejahteraan petani lebih baik dibanding tingkat kesejahteraan petani sebelumnya.

b. Nilai $\mathrm{NTP}=100$, diinterpretasikan petani mengalami impas/break even. Kenaikan/penurunan harga produksi sama dengan persentase kenaikan/penurunan harga konsumsi dan biaya prouksi. Atau dengan kata lain tingkat kesejahteraan petani tidak mengalami perubahan

c. Nilai NTP $<100$, berarti petani mengalami defisit. Harga produksinya naik lebih kecil dari kenaikan harga konsumsi dan biaya produksi.
Tingkat kesejahteraan petani pada suatu periode mengalami penurunan dibanding tingkat kesejahteraan petani pada periode sebelumnya.

Indikator NTP yang dibangun BPS mempunyai unit analisis nasional dan regional (provinsi). NTP nasional merupakan agregasi dari NTP regional sehingga di samping analisis yang bersifat nasional, NTP dapat didisagregasi menjadi unit NTP provinsi. Dengan demikian, di samping dapat diketahui indikator kesejahteraan petani nasional juga dapat diketahui dan diperbandingkan tingkat kesejahteraan petani antarregional provinsi. Dengan metode disagregasi juga dapat dilakukan analisis NTP dari komponen/unsur dari sisi pembentuknya, yaitu sub sektor maupun komoditas. Dengan demikian, NTP dapat pula diturunkan dalam NTP sub sektor (NTP sub sektor tanaman pangan, NTP sub sektor hortikultura, NTP sub sektor perkebunan, NTP sub sektor peternakan, dan NTP sub sektor perikanan) dan NTP komoditas penyusun sub sektor (contohnya NTP padi, NTP palawija, NTP sayur-sayuran, NTP ternak unggas, dan sebagainya). Di samping sebagai komponen penyusun NTP, nilai tukar komponen penyusun NTP itu sendiri merupakan parameter penting kebijakan pembangunan pertanian (Rahmat dan Nuryanti, 2015)

\section{Diagram Timbang NTP}

Dalam penghitungan NTP diperlukan paket komoditas dan bobot pada tahun dasar yang disebut diagram timbang, yang menggambarkan pola produksi dan pola konsumsi masyarakat di perdesaan pada tahun dasar. Diagram timbang NTP yang digunakan saat ini adalah diagram timbang tahun 2012.Paket komoditas (commodity basket) dan diagram timbang hasil SPDT NTP menghasilkan paket perhitungan indeks NTP yaitu Indeks Harga yang Diterima (It) oleh petani dan Indeks Harga yang Dibayar (Ib) oleh petani. Indeks harga yang diterima petani (It) merupakan rata-rata harga produsen dari hasil produksi petani sebelum ditambah biaya pengangkutan dan biaya pengepakan ke dalam harga penjualannya (harga di sawah/ladang setelah pemetikan). Rata-rata harga yang dimaksud yakni harga yang bila dikalikan dengan volume penjualan petani akan mencerminkan total uang yang diterima petani. Indeks harga yang diterima petani (It)dapatmenggambarkan fluktuasi harga komoditas pertanianyang dihasilkan petani. Bahkan indeks ini digunakan jugasebagai data penunjang dalam penghitunganPendapatan Domestik Bruto (PDB)/PendapatanDomestik Regional Bruto (PDRB) sektor pertanian. Penimbang yang digunakan untuk It adalah nilaiproduksi yang dijual petani dari setiap jenis komoditas pertanian.Sebagai data pokok untuk penghitungan diagram timbang inidiperlukan tiga macam data yaitu kuantitas produksi, hargaprodusen, dan persentase nilai komoditas pertanian yang dijualterhadap total nilai produksi (marketed surplus).Pada kelompok indeks harga yang dibayar petani (Ib) mengambarkan rata-rata harga eceran 
barang dan jasa yang dikonsumsi petani, baik untuk memenuhi kebutuhan rumah tangganya sendiri maupun untuk biaya produksi pertanian.Indeks konsumsi rumah tangga menunjukan fluktuasiharga barang/jasa yang dikonsumsi oleh petani yangmerupakan bagian terbesar dari masyarakat diperdesaan dan dapat juga digunakan sebagai proxyinflasi perdesaan. Di sisi lain, indeks biaya produksidan penambahan barang modal menunjukan fluktuasiharga barang/jasa yang digunakan untukmemproduksi komoditas pertanian.

Survei Penyempurnaan Diagram Timbang Nilai Tukar Petani (SPDT-NTP) dilakukan pada Blok Sensus terpilih yang terdapat di perdesaan (rural areas) yang tersebar di 34 provinsi di Indonesia yang mencakup semua sub sektor pertanian. Responden dalam survei ini adalah rumah tangga pertanian terpilih yang meliputi rumah tangga pertanian Tanaman Pangan, Hortikultura, Perkebunan (Perkebunan Rakyat), Peternakan, Perikanan (Penangkapan Ikan dan Budidaya Ikan), dan Kehutanan. Materi pendataan meliputi pendapatan rumah tangga pertanian dari hasil produksi pertanian dan pengeluaran rumah tangga pertanian baik untuk keperluan produksi maupun konsumsi rumah tangga. (BPS, 2017).

Komponen indeks harga yang diterima petani (It) meliputi subsektor tanaman pangan yang terdiri dari tanaman padi dan palawija, subsektor hortikultura terdisi dari tanaman sayur-sayuran, tanaman buahbuahan dan tanaman obat-obatan, subsektor perkebunan terdiri dari tanaman perkebunan rakyat, subsektor peternakan terdiri dari ternak besar, tenak kecil, ternak unggas, dan hasil ternak, subsektor perikanan terdiri dari perikanan tangkap dan budidaya. Menurut BPS, dalam perhitungan NTP komponenkomponen yang mempengaruhi dalam perhitungan tersebut, yaitu komponen konsumsi rumah tangga dan komponen biaya produksi dan penambahan barang modal (BPPBM). Adapun penjelasan komponenkomponen NTP sebagai berikut :

a. Komponen Konsumsi Rumah Tangga

Sumber data komponen konsumsi rumah tangga diperoleh dari hasil SPDT NTP 2012 yaitu mengenai konsumsi/pengeluaran rumah tangga. Karena penimbang yang diinginkan adalah nilai konsumsi total seluruh rumah tangga petani selama setahun, maka nilai konsumsi yang didapat dari hasil SPDT NTP 2012 ini harus dikalikan dengan jumlah rumah tangga tani di perdesaan dalam periode waktu selama setahun. Untuk Subkelompok Makanan, karena data SPDT NTP 2012 khusus Subkelompok Makanan adalah dalam mingguan, maka harus dikalikan dengan banyaknya minggu dalam setahun (dalam hal ini 52,14 minggu), sementara untuk Subkelompok Bukan Makanan data sudah dalam setahun.

b. Biaya Produksi dan Penambahan Barang Modal (BPPBM)
Biaya produksi dan penambahan barang modal terdiri dari biaya bibit, pupuk, obat-obatan, dan pakan, biaya sewa dan pengeluaran lainnya, transportasi, barang modal dan upah buruh tani. Penimbang untuk kelompok ini adalah pengeluaran ongkos-ongkos atau biaya yang dikeluarkan petani (tidak termasuk ongkos/biaya produksi yang berasal dari produksi sendiri). Data tersebut didapat dari hasil pengolahan SPDT NTP 2012 dan disesuaikan dengan Survei Struktur Ongkos Pertanian (SOUT).

\section{Sumber Data}

Analisis dalam penelitian ini menggunakan data kuantitatif, berupa data sekunder yang bersumber dari Badan Pusat Statistik (BPS) Provinsi Bali. Data yang digunakan dalam penelitian ini merupakan data hasil Survei Nilai Tukar Petani dengan Metode Nilai Produksi yang terintegrasi dengan Survei Harga Perdesaan tahun 2015-2017.Lokasi penelitian ini dilakukan di Provinsi Bali. Penentuan lokasi penelitian dilakukan dengan metode purposive sampling, yakni suatu metode penentuan lokasi penelitian yang ditentukan dengan secara sengaja didasarkan pada pertimbangan secara geografis Provinsi Bali mempunyai bentang alam yang unik dan indah, namun demikian potensi pertanian Bali tidak bisa dipandang sebelah mata. Sektor pertanian merupakan salah satu pilar utama ekonomi Bali.

\section{PEMBAHASAN}

\section{Subsektor Tanaman Pangan (NTP-P)}

Berdasarkan data series bulanan NTP Subsektor Tanaman Pangan (NTP-P) tahun 2015-2017 (gambar1) tercatat secara garis besar berada pada posisi dibawah nilai 100 , yakni masing-masing sebesar 97,28; 97,24; dan 95,45. Kendati demikian NTP 2015 Bulan Oktober sampai Desember tercatat lebih dari 100. Dengan demikian petani subsektor tanaman pangan dapat dikatakan mengalami defisit atau dengan kata lain tingkat kesejahteraan petani dan daya beli petani Bali subsektor tanaman pangan masih dibawah standar. Secara teori capaian NTP subsektor tanaman pangan ini diartikanbahwa nilai yang diterima dari hasil pertanian tanaman pangan belum mampu mencukupi kebutuhan konsumsi rumah tangga dan biaya produksinya.

Komoditas padi merupakan komoditas pokok untuk kebutuhan pangan bagi Indonesia. Sehingga menjadi komoditas pertanian yang strategis. Tentunya komoditas padi dan tanaman pangan pada umumnya mendapat perhatian khusus. Jika melihat rata-rata NTP subsektor tanaman pangan cenderung lebih rendah dari pada subsektor lain. Hal ini dipengaruhi oleh masa panen raya pada komoditas padi. Pada masa panen raya padi (sekitar Bulan April - Mei) jumlah ketersediaan padi meningkat dan harga padi cenderung menurun. Kondisi demikian menyebabkan NTP padi berada pada posisi rendah. 
Misalnya pada pada gambar 1 terlihat pada Mei 2015 dan Mei 2017 posisi NTP berapa pada level 93,21 dan 93,17. Menjadikan trend NTP paling rendah dalam tiga tahun terakhir.

Rendahnya harga padi bukan satu-satunya penyebab penurunan nilai NTP, tetapi lebih diakibatkankarena sistem tataniaga padi yang mengakibatkan petani sebagai penerima harga dan belum efektifnya kebijakan harga dasar gabah. Sebaliknya pada masa paceklik (Bulan Oktober - Desember) harga padi dan NTP padicenderung meningkat karena jumlah ketersediaan padi dipasaran semakin berkurang sedangkan permintaan pasar meningkat. Terlebih lagi banyak petani padi di Bali yang menggunakan pemanenan sistem tebas sehingga mengakibatkan makin berkuranganya penerimaan harga gabah di level petani.

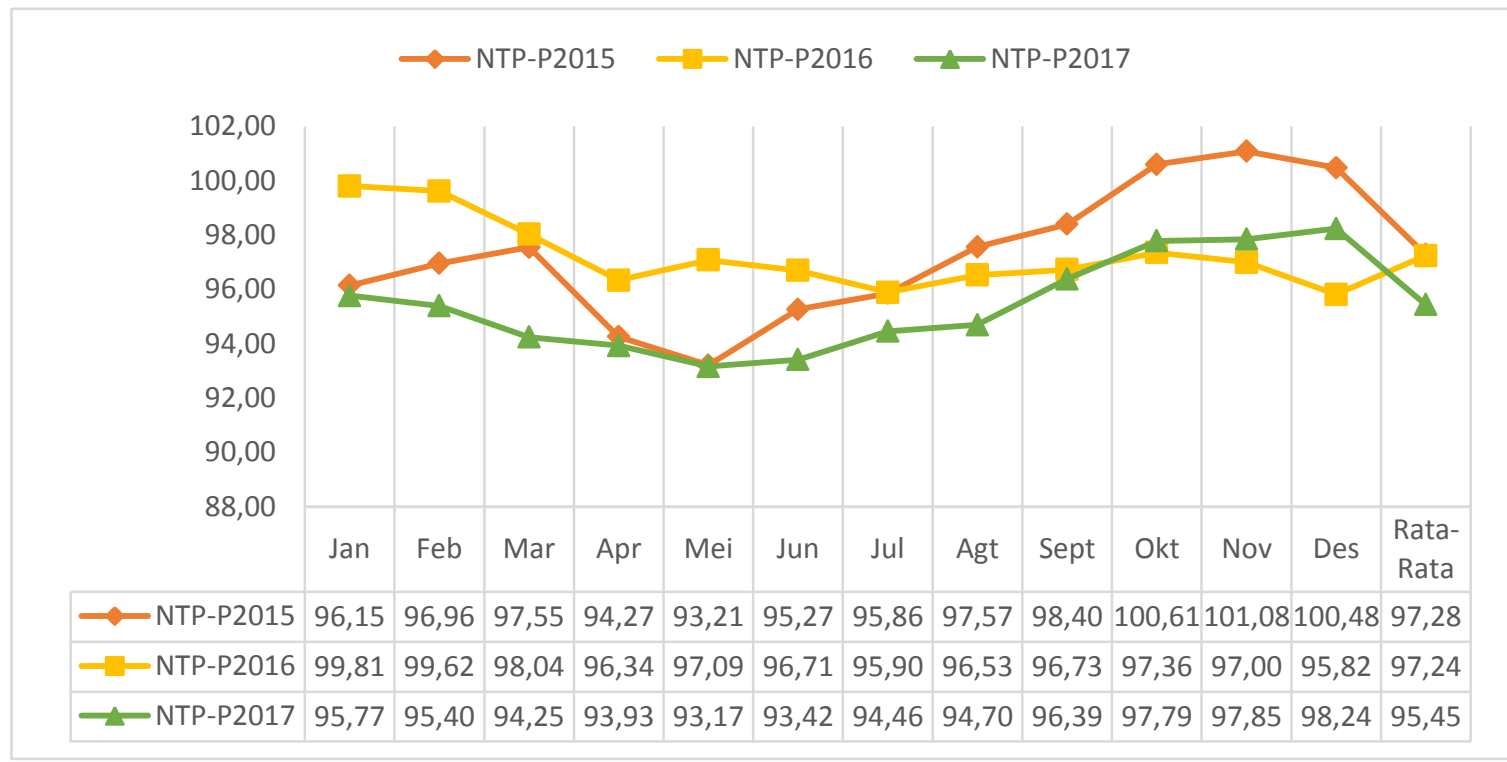

Gambar 1. Perkembangan Nilai Tukar Petani Subsektor Tanaman Pangan (NTP-P)

Provinsi Bali Tahun 2015 - 2017(Tahun 2012=100)

Sumber: BPS Provinsi Bali, 2017 (Diolah)

Indeks harga yang diterima petani (It) pada subsektortanaman pangan tahun 2015-2017 mengalami peningkatan sebesar 5,39 persen. Peningkatan tersebut terjadi pada kelompok padi sebesar 2,81 persen dan palawija sebesar 11,54 persen. Kompenen indeks yang diterima petani (It) komoditas padi mengalami pertumbuhan yang cenderung lebih lambat dari komoditas lain di subsektor tanaman pangan. Peningkatanlainnya terjadi pada indeks harga yang dibayar petani (Ib) tercatat sebesar 7,19 persen. Peningkatan pada Ib dipengaruhi oleh naiknya Indeks Harga Konsumsi Rumah Tangga (IHKP) sebesar 7,35 persen, dan indeks Biaya Produksi dan Penambahan Barang Modal (BPPBM) sebesar 6,43 persen.

Tabel 1. Rata-Rata Indeks Nilai Tukar Petani Subsektor Tanaman Pangan (NTP-P) dan Perubahannya Provinsi Bali Tahun $2015-2017$ (Tahun 2012=100)

\begin{tabular}{|c|c|c|c|c|c|}
\hline \multirow{2}{*}{ Komponen Indeks } & \multicolumn{3}{|c|}{ Rata-Rata NTP-P } & \multirow{2}{*}{$\begin{array}{c}\text { Rata-Rata } \\
\text { NTP-P 2015- } \\
\mathbf{2 0 1 7}\end{array}$} & \multirow{2}{*}{$\begin{array}{c}\text { Persentase } \\
\text { Perubahan } \\
2015 \text { - 2017 } \\
(\%)\end{array}$} \\
\hline & 2015 & 2016 & 2017 & & \\
\hline Indeks Harga yang Diterima Petani (It) & 116,48 & 121,70 & 122,76 & 120,31 & 5,39 \\
\hline Padi & 114,74 & 118,18 & 117,97 & 116,97 & 2,81 \\
\hline Palawija & 122,60 & 131,97 & 136,74 & 130,44 & 11,54 \\
\hline Indeks Harga yang Dibayar Petani (Ib) & 119,98 & 125,15 & 128,61 & 124,58 & 7,19 \\
\hline Konsumsi Rumah Tangga & 120,73 & 126,37 & 129,61 & 125,57 & 7,35 \\
\hline ВРРВМ & 116,49 & 119,52 & 123,99 & 120,00 & 6,43 \\
\hline
\end{tabular}

Sumber: BPS Provinsi Bali, 2017 (Diolah) 


\section{Subsektor Hortikultura (NTP-H)}

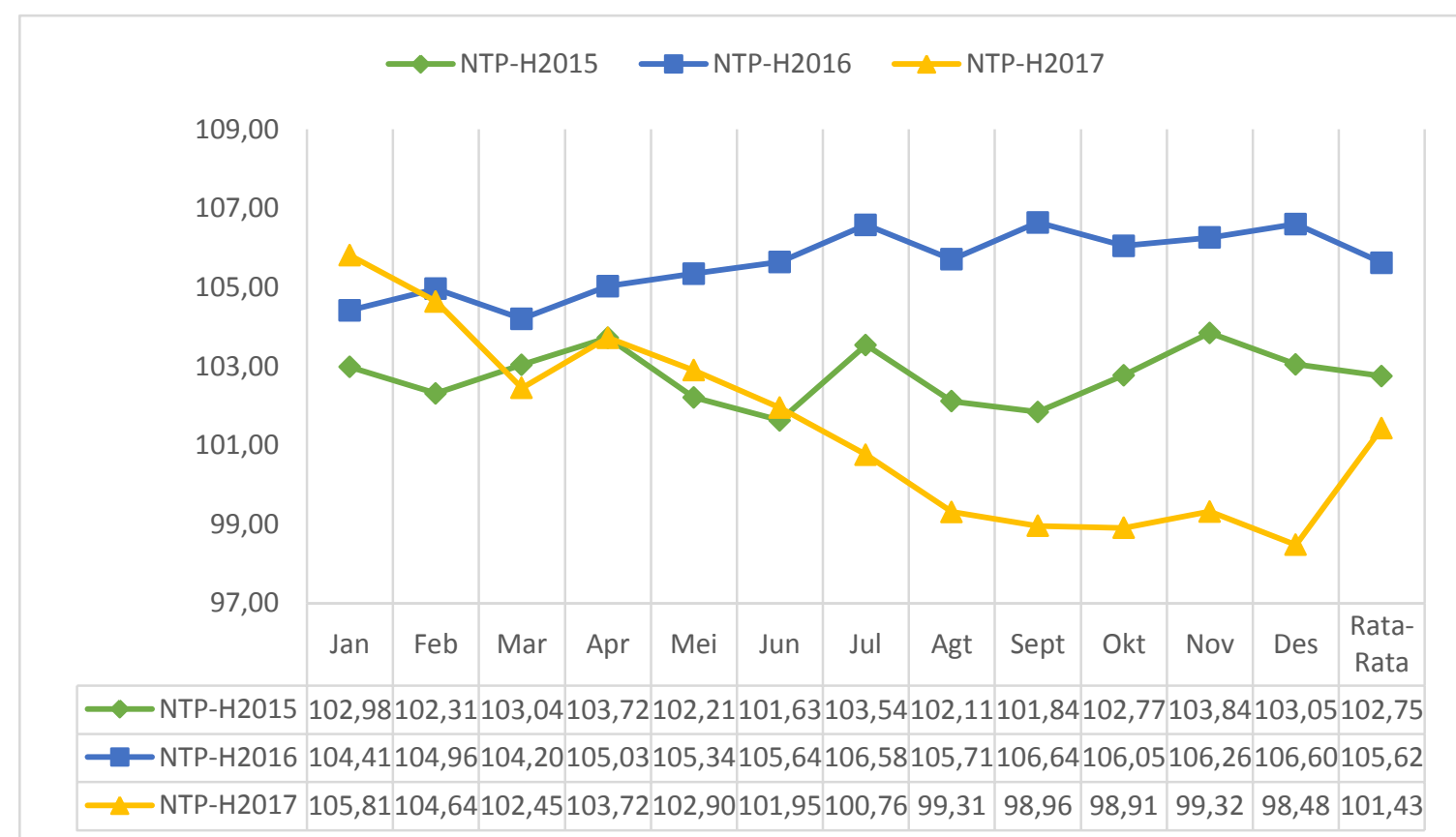

Gambar 2. Nilai Tukar Petani Subsektor Hortikultura (NTP-H) Provinsi Bali Tahun 2015 - 2017 (Tahun 2012=100)

Sumber: BPS Provinsi Bali, 2017 (diolah)

Secara rata-rata Indeks NTP Sub sektor Hortikultura (NTP-H) pada 2015-2017 berada diatas nilai 100 . Kendati rata-rata NTP 2017 diatas 100 dan mengalami penurunan dibanding nilai NTP tahun sebelumnya dari 105,62 menjadi 101,43. Hal ini disebabkan pada Agustus sampai Desember 2017terjadi penurunan nilai NTP sampai dibawah nilai 100.

Indeks harga yang diterima petani (It) mengalami peningkatan sebesar 5,39 persen atau naik dari 120,96 menjadi 127,49 . Kondisi ini dipengaruhi oleh naiknya komponen indeks harga kelompok sayur-sayuran 16,18 persen, buah-buahan 0,20 persen, meskipun kelompok tanaman obat turun sebesar 4,70 persen. Untuk indeks yang dibayar petani (Ib) juga mengalami kenaikan sebesar 6,78 persen yaitu naik dari 117,72 menjadi 125,70 . Peningkatan tersebut dipengaruhi oleh indeks harga barang konsumsi rumah tangga petani naik 7,31 persen dan indeks Biaya Produksi dan Penambahan Barang Modal (BPPBM) 5,24 persen. Nilai lebih rinci disajikan pada Tabel 2.

Tabel 2 Rata-Rata Indeks Nilai Tukar Petani SubsektorHortikultura (NTP-H) dan Perubahannya Provinsi Bali Tahun $2015-2017$ (Tahun 2012=100)

\begin{tabular}{|c|c|c|c|c|c|}
\hline \multirow{2}{*}{ Komponen Indeks } & \multicolumn{3}{|c|}{ Rata-Rata NTP-H } & \multirow{2}{*}{$\begin{array}{c}\text { Rata-Rata } \\
\text { NTP-H 2015- } \\
2017\end{array}$} & \multirow{2}{*}{$\begin{array}{c}\text { Persentase } \\
\text { Perubahan 2015 - } \\
2017(\%)\end{array}$} \\
\hline & 2015 & 2016 & 2017 & & \\
\hline Indeks Harga yang Diterima Petani (It) & 120,96 & 129,19 & 127,49 & 125,88 & 5,39 \\
\hline Sayur-sayuran & 128,94 & 142,74 & 149,81 & 140,50 & 16,18 \\
\hline Buah-buahan & 117,40 & 123,22 & 117,64 & 119,42 & 0,20 \\
\hline Tanaman Obat & 122,14 & 121,63 & 116,40 & 120,06 & $-4,70$ \\
\hline Indeks Harga yang Dibayar Petani (Ib) & 117,72 & 122,31 & 125,70 & 121,91 & 6,78 \\
\hline Konsumsi Rumah Tangga & 119,68 & 125,14 & 128,43 & 124,42 & 7,31 \\
\hline ВРPBM & 112,39 & 114,64 & 118,28 & 115,11 & 5,24 \\
\hline
\end{tabular}

Sumber: BPS Provinsi Bali, 2017 (diolah) 


\section{Subsektor Perkebunan Rakyat(NTP-Pr)}

Indeks NTP Subsektor Tanaman Perkebunan Rakyat (NTP-Pr) pada 2015-2017 tercatat cukup fluktuatif. Tahun 2015 tercacat 99,97kemudian naik menjadi 104,50. Capaian sejak tahun 2016 sampai saat ini tidak lepas karena hasil data tiap bulan yang mencapai diatas nilai 100. Hal ini berarti indeks NTP Subsektor
Tanaman Perkebunan Rakyat dapat dikatakan mengalami surplus atau mampu mencukupi kebutuhan konsumsi rumah tangga dan biaya produksinya. Walaupun dalam tiga tahun ini Indeks NTP-Pr sempat mengalami penurunan sampai pada level 96,83persen yaitu pada Bulan Maret 2015.

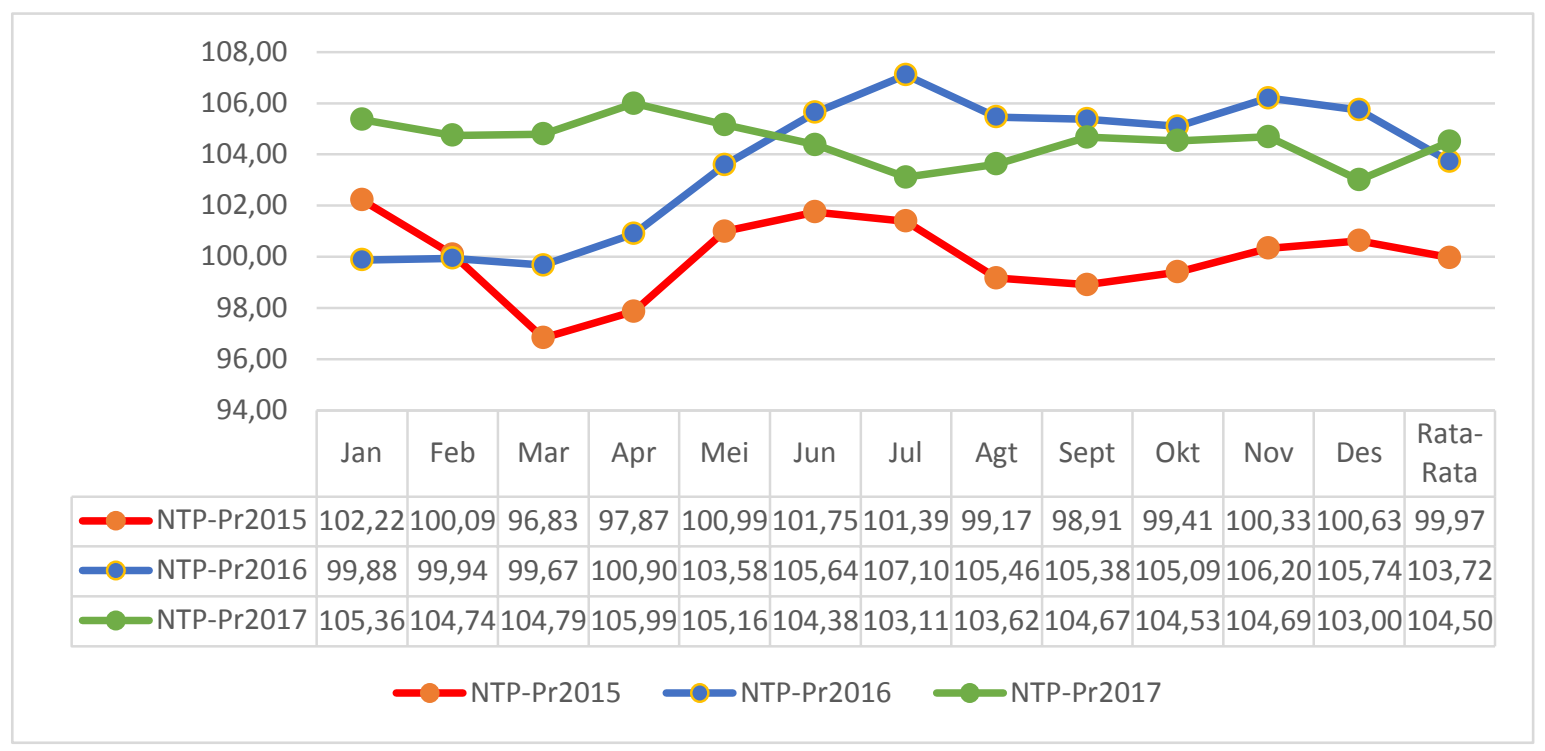

Gambar 3. Nilai Tukar Petani Subsektor Perkebuanan Rakyat (NTP-Pr) Provinsi Bali Tahun 2015 - 2017 (Tahun 2012=100)

Sumber: BPS Provinsi Bali, 2017 (diolah)

Kenaikan indeks harga yang diterima petani (It) sebesar 11,72 persen dimana pada indeks ini hanya terdapat satu komponen indeks harga yaitu tanaman perkebunan rakyat.Kenaikan tersebut secara komulatif terjadi dari 2015 - 2017, yakni dari 116,80 menjadi 130,49 persen.Sementara itu, indeks yang dibayar petani (Ib) juga naik sebesar 6,87 persen. Kenaikan tersebut indeks yang dibayar petani (Ib) pada subsektor perkebunan rakyat dipengaruhi oleh naiknya indeks konsumsi rumah tangga yaitu 7,5 persen dan indek BPPBM sebesar 4,76 persen. Subsektor initercacat tidak ada penurunan nilai indeks. Informasi tersebut lebih rinci dijabarkan pada tabel 3.

Tabel 3. Rata-Rata Nilai Tukar Petani Subsektor Perkebunan Rakyat (NTP-Pr) dan Perubahannya Provinsi Bali Tahun $2015-2017$ (Tahun 2012=100)

\begin{tabular}{|c|c|c|c|c|c|}
\hline \multirow{2}{*}{ Komponen Indeks } & \multicolumn{3}{|c|}{ Rata-Rata NTP-Pr } & \multirow{2}{*}{$\begin{array}{c}\text { Rata-Rata } \\
\text { NTP-Pr } \\
\text { 2015-2017 }\end{array}$} & \multirow{2}{*}{$\begin{array}{c}\text { Persentase } \\
\text { Perubahan 2015 } \\
-2017(\%)\end{array}$} \\
\hline & 2015 & 2016 & 2017 & & \\
\hline Indeks Harga yang Diterima Petani (It) & 116,80 & 126,11 & 130,49 & 124,47 & 11,72 \\
\hline Tanaman Perkebunan Rakyat & 116,80 & 126,11 & 130,49 & 124,47 & 11,72 \\
\hline Indeks Harga yang Dibayar Petani (Ib) & 116,84 & 121,57 & 124,88 & 121,10 & 6,87 \\
\hline Konsumsi Rumah Tangga & 120,11 & 125,76 & 129,12 & 125,00 & 7,50 \\
\hline ВРPBM & 107,04 & 109,00 & 112,13 & 109,39 & 4,76 \\
\hline
\end{tabular}

Sumber: BPS Provinsi Bali, 2017 (diolah) 


\section{Subsektor Peternakan (NTP-Pt)}

Subsektorpeternakan terdiri atas ternak besar, ternak kecil, unggas, dan hasil ternak. Indeks NTP Subsektorpeternakan (NTP-Pt) pada 2015-2017 tercatat mengalami surplus karena lebih dari 100 dengan rincian masing-masing 2015 sebesar 113,38; 2016 sebesar 115,20 dan 2017 sebesar 114,23.
Peningkatan nilai NTP-Pt tersebut tidak lepas dari hasil yang cukup baik selama tiga tahun terakhir. Dalam kurun waktu tersebut trend pada September cenderung meningkat, sampai pada puncaknnya di tahun 2016 yang mencapai 117,73.

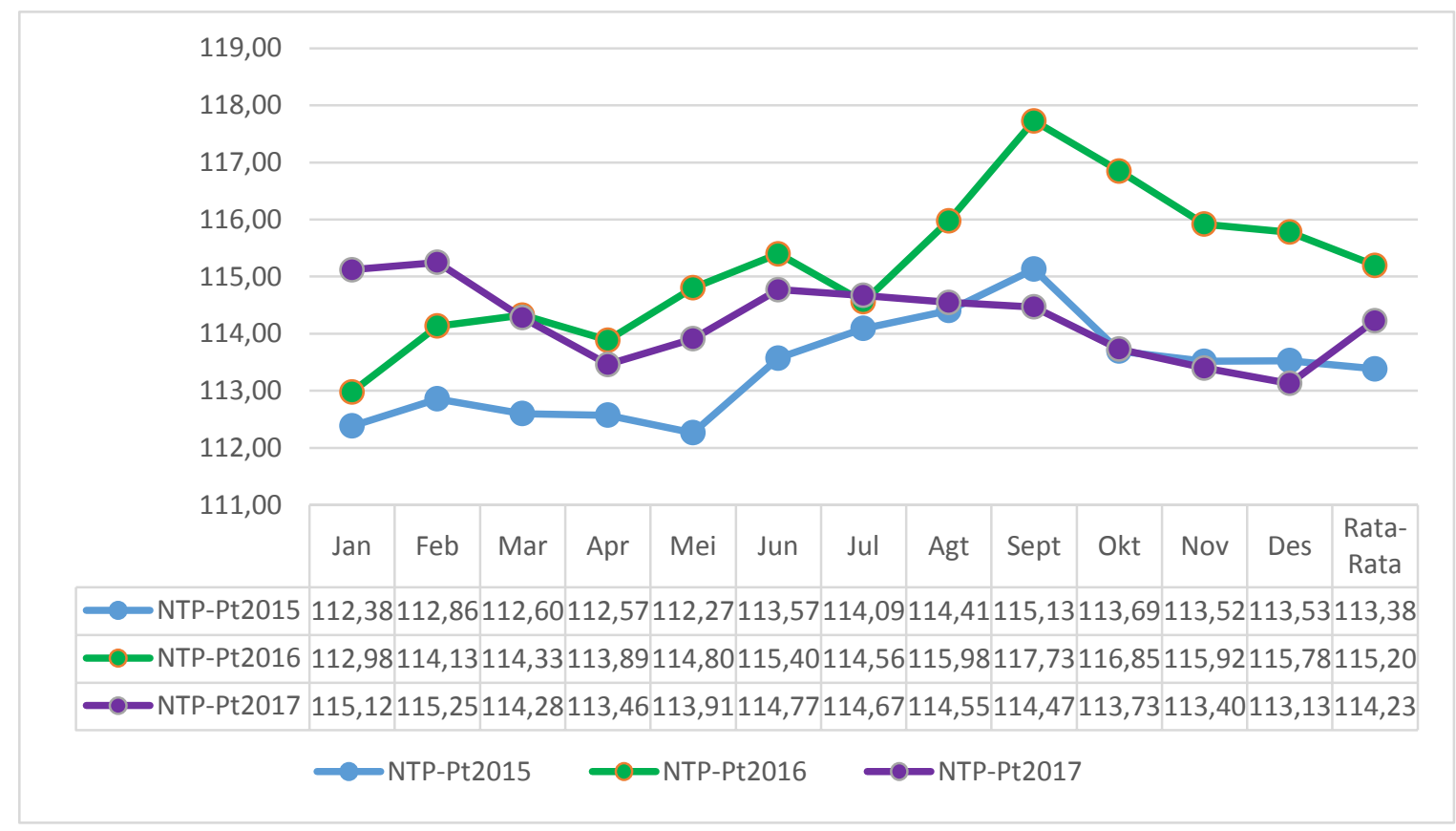

Gambar 4. Nilai Tukar Petani Subsektor Peternakan (NTP-Pt) Provinsi Bali Tahun 2015 -2017 (Tahun 2012=100)

Sumber: BPS Provinsi Bali, 2017 (diolah)

Berdasarkan data pada tabel 4indeks harga yang diterima petani (It) mengalami kenaikan mencapai 6,28 persen. Hal ini dipengaruhi oleh nilai indeks ternak besar, unggas, dan hasil ternak masing-masing 9,00 persen, 6,27 persen, dan 4,80 persen. Penurunan terjadi pada indek harga ternak kecil yang mencapai
0,80 pesen. Sedangkan dari sisi indeks harga yang dibayarkan (Ib) juga mengalami kenaikan sebesar 5,50 persen. Kenaikan tersebut terdiri dari indeks harga konsumsi rumah tangga sebesar 7,21 persen dan indeks biaya produksi dan penambahan barang modal (BPPBM) sebesar 3,84 persen.

Tabel 4 Rata-Rata Nilai Tukar Petani Subsektor Peternakan (NTP-Pt) dan Perubahannya Provinsi Bali Tahun $2015-2017$ (Tahun 2012=100)

\begin{tabular}{lccccc}
\hline \multirow{2}{*}{ Komponen Indeks } & \multicolumn{2}{c}{ Rata-Rata NTP-Pt } & Rata-Rata & $\begin{array}{c}\text { Persentase } \\
\text { NTP-Pt }\end{array}$ & $\begin{array}{c}\text { Perubahan 2015 - } \\
\mathbf{2 0 1 7}(\mathbf{\%})\end{array}$ \\
\hline Indeks Harga yang Diterima Petani (It) & $\mathbf{2 0 1 5}$ & $\mathbf{2 0 1 6}$ & $\mathbf{2 0 1 7}$ & $\mathbf{2 0 1 5 - 2 0 1 7}$ & 6,28 \\
Ternak Besar & 129,07 & 135,46 & 137,18 & 133,91 & 9,00 \\
Ternak Kecil & 131,00 & 140,52 & 142,79 & 138,10 & $-0,80$ \\
Unggas & 132,13 & 129,96 & 131,08 & 131,06 & 6,27 \\
Hasil Ternak & 126,79 & 132,83 & 134,75 & 131,46 & 4,80 \\
Indeks Harga yang Dibayar Petani (Ib) & 115,09 & 120,77 & 120,61 & 118,82 & 5,50 \\
Konsumsi Rumah Tangga & 113,83 & 117,59 & 120,10 & 117,17 & 7,21 \\
BPPBM & 120,29 & 125,67 & 128,97 & 124,98 & 3,84 \\
\hline
\end{tabular}

Sumber: BPS Provinsi Bali, 2017 (diolah) 


\section{Subsektor Perikanan (NTP-Pi)}

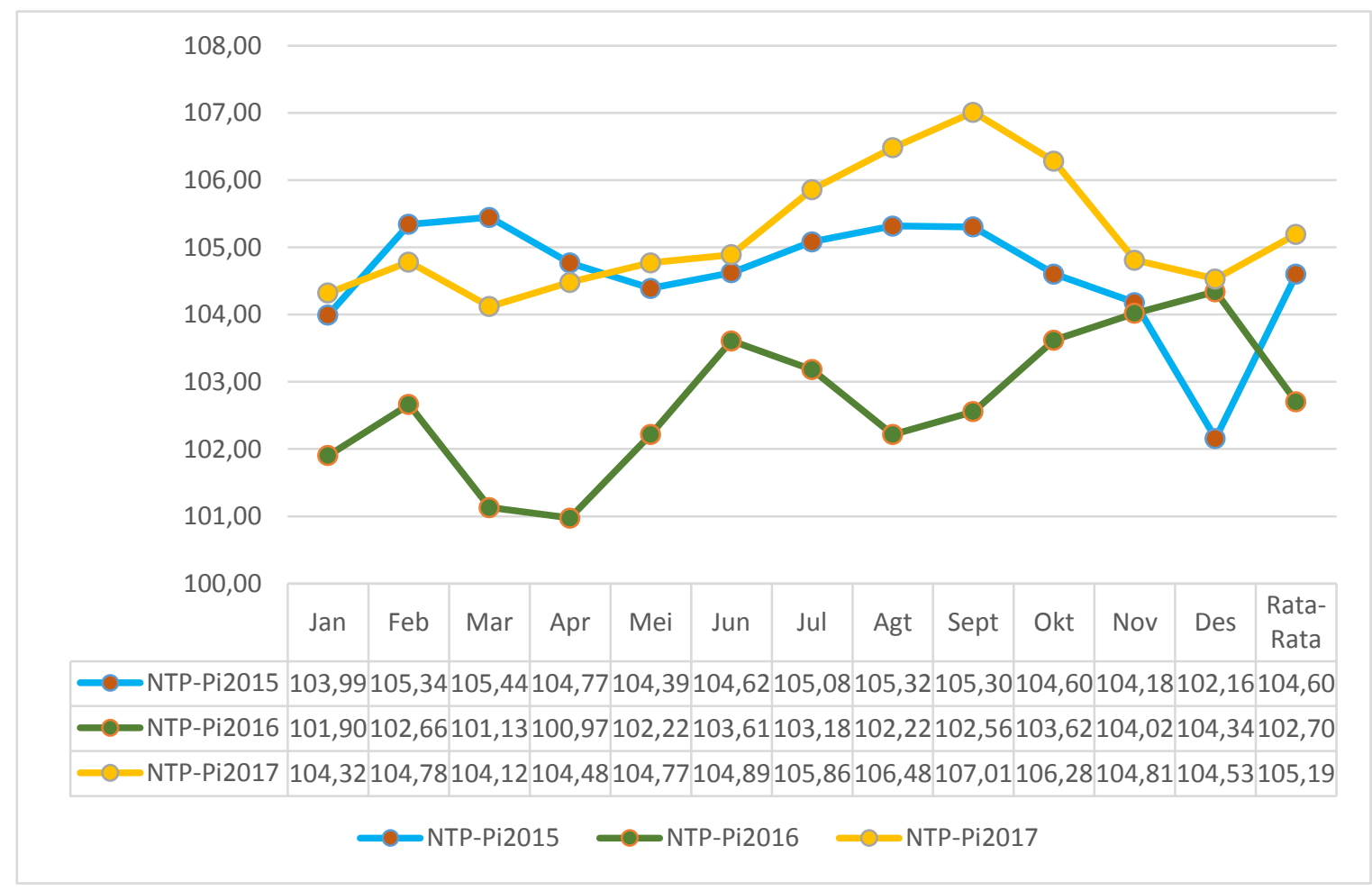

Gambar 5. Nilai Tukar Petani Subsektor Perikanan (NTP-Pi) Provinsi Bali Tahun 2015 - 2017 (Tahun 2012=100)

Sumber: BPS Provinsi Bali, 2017 (diolah)

Subsektor Perikanan mencakup kegiatan perikanan tangkap dan budidaya perikanan. Sama halnya dengan subsektor perkebunan rakyat, berdasarkan Gambar 5 dapat dikatakan indeks NTP Subsektorperikanan (NTP-Pi) mengalami surplus. Karena dari catatan tahun 2015-2017 nilai NTP-Pi berada diatas nilai 100. Dari tiga tahun tersebut capaian NTP-Pi paling tinggi pada tahun 2017 yaitu mencapai 105,19. Indeks harga dari hasil produksi yang diterima petani (It)6,50 persen. Meliputi komoditas ikan tangkap sebesar 8,54 pesen dan komoditas ikan budidaya sebesar 2,64 persen. Sementara itu untuk indeks harga yang dibayar petani mencapai 5,89 persen yang meliputi indeks harga konsumsi rumah tangga petani sebesar 8,31 persen, sedangkan indeks BPPBM 0,29 persen. Rata-rata NTP-Pi tiga tahun terakhir pada indeks yang diterima petani untuk perikanan tangkap mencapai level yang paling tinggi yaitu sebesar 140,91 . Berarti daya beli nelayan perikanan tangkap cukup baik.

Tabel 5 Rata-Rata Nilai Tukar Petani SubsektorPerikanan (NTP-Pi) dan Perubahannya Provinsi Bali Tahun $2015-2017$ (Tahun 2012=100)

\begin{tabular}{lccccc}
\hline \multirow{2}{*}{ Komponen Indeks } & \multicolumn{2}{c}{ Rata-Rata NTP-Pi } & Rata-Rata & $\begin{array}{c}\text { Persentase } \\
\text { NTP-Pi } \\
\text { Perubahan 2015 - } \\
\text { 2017 (\%) }\end{array}$ \\
\hline Indeks Harga yang Diterima Petani (It) & $\mathbf{2 0 1 5}$ & $\mathbf{2 0 1 6}$ & $\mathbf{2 0 1 7}$ & $\mathbf{2 0 1 5 - 2 0 1 7}$ & $\mathbf{2 0 1 5}$ \\
$\quad$ Tangkap & 124,49 & 126,59 & 132,58 & 127,89 & 8,54 \\
Budidaya & 136,29 & 138,49 & 147,93 & 140,91 & 2,64 \\
Indeks Harga yang Dibayar Petani (Ib) & 107,00 & 108,93 & 109,83 & 108,59 & 5,89 \\
$\quad$ Konsumsi Rumah Tangga & 119,02 & 123,25 & 126,04 & 122,77 & 8,31 \\
BPPBM & 123,47 & 130,04 & 133,73 & 129,08 & 0,29 \\
\hline
\end{tabular}

Sumber: BPS Provinsi Bali, 2017 (diolah) 
Nilai Tukar Petani 2015 - 2017

Perhitungan Nilai Tukar Petani tahun 2015-2017 menggunakan tahun dasar $2012=100$. Dari perhitungan disemua subsektor pertanian menunjukan perubahan indeks Nilai Tukar Petani dari tahun 2015 2017 cukup beragam. Nilai NTP untuk subsektor tanaman pangan dan hortikultura mengalami penurunan masing-masing 1,89 persen dan 1,28 persen. Selama tiga tahun tersebut daya beli pada subsektor tanaman pangan berada di bawah tahun 2012 dan menjadi subsektor yang NTPnya terendah.
Sedangkan persentase perubahan paling tinggi yaitu subsektor Tanaman Perkebunan Rakyat sebesar 4,54 persen. Kendati tahun 2015 NTP dibawah 100 yakni sebesar 99,97. Disisi lain subsektor peternakan dan perikanan kenaikan persentase perubahan NTP juga tergolong kecil yaitu masing-masing 0,74 dan 0,57. Secara keseluruhan rata-rata NTP dalam tiga tahun terakhir sebesar 105,03 dan persentase perubahan sebesar 0,47 persen. Kendati secara keseluruhan kenaikan keiakan NTP tergolong kecil, NTP gabungan menunjukkan trend yang meningkat yaitu mencapai angka yang diatas 100 .

Tabel 6 Rata-Rata Nilai Tukar Petani Menurut Subsektor dan Perubahannya Provinsi Bali Tahun 2015 - 2017(Tahun 2012=100)

\begin{tabular}{|c|c|c|c|c|c|}
\hline \multirow[b]{2}{*}{ NTP Subsektor } & \multicolumn{3}{|c|}{ Rata-Rata NTP } & Rata-Rata & \multirow{2}{*}{$\begin{array}{c}\text { Persentase } \\
\text { Perubahan 2015 } \\
\text { - 2017 }(\%)\end{array}$} \\
\hline & 2015 & 2016 & 2017 & $\begin{array}{c}\text { NTP } \\
2017\end{array}$ & \\
\hline 1. Tanaman Pangan & 97,28 & 97,24 & 95,45 & 96,66 & $-1,89$ \\
\hline 2. Hortikultura & 102,75 & 105,62 & 101,43 & 103,27 & $-1,28$ \\
\hline 3. Tanaman Perkebunan Rakyat & 99,97 & 103,72 & 104,50 & 102,73 & 4,54 \\
\hline 4. Peternakan & 113,38 & 115,20 & 114,23 & 114,27 & 0,74 \\
\hline 5. Perikanan & 104,60 & 102,70 & 105,19 & 104,17 & 0,57 \\
\hline NTP Gabungan & 104,20 & 106,19 & 104,69 & 105,03 & 0,47 \\
\hline
\end{tabular}

Sumber: BPS Provinsi Bali, 2017 (diolah)

Gambar 6 menunjukan NTP yang dirinci menurut bulan, sehingga menggambarkan trend NTP. Dalam tiga tahun terakhir, secara komulatif rata-rata NTP tahun 2016 berada pada posisi paling tinggi yakni sebesar 106,19. Peningkatan tersebut tercermin pada Mei - September 2016. Kendati Oktober - Desember 2016 cenderung agak menurun tetapi posisi NTP 2016 masih berada diatas tahun 2015 dan 2017. Terlihat NTP tahun 2015 berada pada posisi terendah dengan nilai sebesar 104,20. Meskipun demikian secara umum rata-rata NTP Bali berada ada posisi diatas 100 yang berarti daya beli petani sudah cukup sejahtera. Pada Juli - Desember 2017 trend atau arah nilai NTP cenderung berada di bawah trend NTP tahun 2015 dan 2016.Pada bulan tersebut NTP terendah mencapai 103,93. Kondisitrend NTP yang demikian kiranya cukup mengkawatirkan bagi petani. Salah satu penyebab penurunan NTP yaitu kenaikan indeks harga barang-barang hasil produksi pertanian lebih kecil dari pada kenaikan indeks harga barang dan jasa yang dibayar petani.

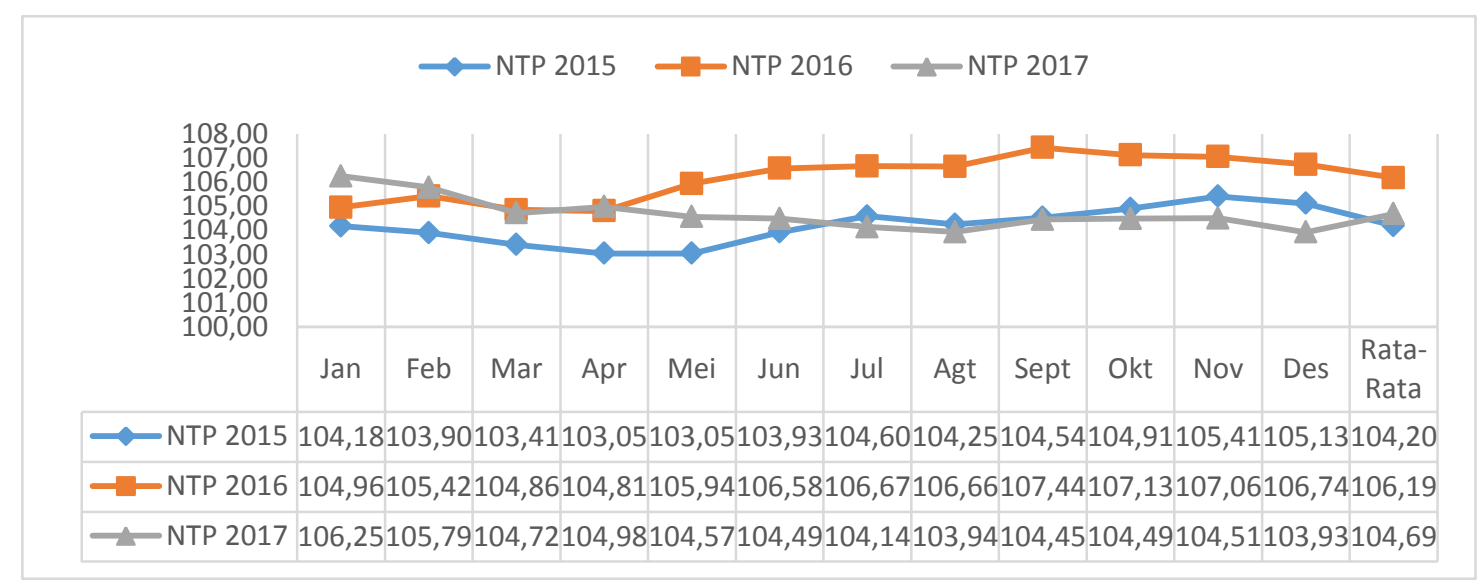

Sumber: BPS Provinsi Bali, 2017 (diolah) 


\section{Faktor-Faktor Yang Mempengaruhi NTP}

Seperti yang dijelaskan sebelumnya bahwa dalam perhitungan NTP terdapat komponen-komponen yang mempengaruhi, yaitu komponen konsumsi rumah tangga dan komponen biaya produksi dan penambahan barang modal. Sumber data konsumsi atau pengeluaran rumah tangga petani berasal dari kegiatan pendataan SPDT-NTP tahun 2012. Adapun yang dimaksud konsumsi rumah tanga antara lain bahan makanan, makanan jadi, minuman, rokok dan tembakau, perumahan, sandang, kesehatan, pendidikan, rekreasi dan olahraga, transportasi dan komunikasi. Sedangkan komponen biaya produksi dan penambahan barang modal meliputi bibit, pupuk, obat-obatan dan pakan, biaya sewa dan pengeluaran lain, transportasi, penambahan barang modal, upah buruh. TrendIndeks yang diterima petani pada tahun 2015 -2017 meningkat. Tercatat dari 121,73 tahun 2015 selanjutnya 128,51 di tahun 2016 menjadi 130,23 tahun 2017. Sebaliknya trend perubahan NTP justru menurun, dari tahun 2015-2016 sebesar 5,57 persen menjadi 1,32 persen tahun $2016-2017$. Faktor yang mempengaruhi komponen yang nilai NTP yang diterima petani adalah nilai indeks dari hasil pertanian, yaitu padi dan palawija (tanaman pangan), sayur-sayuran, buah-buahan, tanaman obat (hortikultura), tanaman perkebunan rakyat (perkebunan), ternak besar, ternak kecil, unggas, hasil ternak (peternakan), perikanan tangkap, perikanan budidaya (perikanan).

Dari hasil analisis terlihat nilai tukar petani tahun 2015 - 2017 pada komponen konsumsi rumah tangga dan biaya produksi dan penambahan barang modal rata-rata diatas nilai 100 dan perubahan komponen NTP cenderung arah posisitf yang berarti indeks harga yang dibayar petani dan peningkatan indeks harga dari tahun ke tahun cukup tinggi. Dengan kata lain tingkat daya beli masyarakat petani di atas daya beli pada tahun dasar 2012. Sebagai contoh pengeluaran petani di tahun 2017 yang masuk tiga besar tertinggi pada komponen makanan jadi, minuman, rokok dan tembakau mencapai 135,91, disusul komponen bahan makanan sebesar 133,04 dan komponen perumahan sebesar 132,97. Rata-rata nilai tukar pada komponen indeks yang dibayar petani pada tahun 2015 dan 2016 yang nilainya lebih dari 130 yaitu komponen bahan makanan mencapai 132,75 . Trend kenaikan harga kebutuhan rumah tangga tersebut dipengaruhi oleh indeks harga konsumen perdesaan (IHKP) atau inflasi perdesaan.

Nilai persentase perubahan NTP tahun $2015-2017$ cukup variatif. Pada tahun 2015 ke 2016 indeks yang dibayar petani komponen biaya produksi dan penambahan barang modal pada transportasi mengalami penurunan yang paling tajam yakni mencapai 3,59 persen. Komponenkonsumsi rumah tangga pada tansportasi dan komunikasimenjadi penurunan yang paling rendah kedua yakni mencapai 1,77 persen. Sementara itu, komponen konsumsi rumah tangga pada bahan makanan selama 2015 2016 mengalami peningkatan paling tinggi yakni mencapai 7,89 persen, disusul komponen makanan jadi, minuman, rokok dan tembakau mencapai 5,81 persen.

Perubahan NTPtahun 2016 - 2017 pada masingmasing komponen semuanya mengalami peningkatan.Peningkatan tiga besar yang tertinggi terjadi pada indeks yang dibayar petani pada konsumsi rumah tangga komponen makanan jadi, minuman, rokok dan tembakau sebesar 6,76 persen, disusul komponen perumahan sebesar 5,64 persen dan koponen penambahan barang modal petani sebesar 4,28 persen. Sedangkan yang menempati tiga besar peningkatan yang terendah terjadi pada indeks yang dibayar petani komponen biaya produksi dan penambahan barang modal pada transportasi sebesar 0,19 persen, disusul komponen konsumsi rumah tangga pada bahan makanan sebesar 0,22 persen dan transportasi dan komunikasi sebesar 0,74 persen. Perubahan NTP tersebut merupakan cerminan perkembangan indeks pada komponen yang mempengaruhi pembentukan NTP. Informasi rata-rata nilai komponen NTP dan persentase perubahannya dari tahun ke tahun secara lebih lengkap dapat dilihat pada tabel 7 . 
Tabel 7. Rata-Rata Nilai KomponenNTP dan Perubahannya Provinsi Bali Tahun 2015 -2017(Tahun 2012=100)

\begin{tabular}{lccccc}
\hline & \multicolumn{2}{c}{ Rata-Rata Nilai Tukar } & \multicolumn{2}{c}{ Perubahan NTP (\%) } \\
\multicolumn{1}{c}{ Komponen Yang Mempengaruhi NTP } & $\mathbf{2 0 1 5}$ & $\mathbf{2 0 1 6}$ & $\mathbf{2 0 1 7}$ & $\mathbf{2 0 1 5}$ ke 2016 & $\begin{array}{c}\mathbf{2 0 1 6} \\
\text { ke }\end{array}$ \\
& & & & & $\mathbf{2 0 1 7}$ \\
\hline a. Indeks Diterima Petani & & & & 1,34 \\
b. Indeks Dibayar Petani & 121,73 & 128,51 & 130,23 & 5,57 & 2,36 \\
- Konsumsi Rumah Tangga & 116,82 & 121,53 & 124,40 & 4,03 & 2,42 \\
Bahan Makanan & 120,25 & 126,04 & 129,09 & 4,81 & 0,22 \\
Makanan Jadi, Minuman, Rokok, dan & 123,04 & 132,75 & 133,04 & 7,89 & 6,76 \\
Tembakau & 120,31 & 127,30 & 135,91 & 5,81 & 5,64 \\
Perumahan & 122,16 & 125,87 & 132,97 & 3,04 & 2,44 \\
Sandang & 118,69 & 123,85 & 126,87 & 4,35 & 4,05 \\
Kesehatan & 117,52 & 121,96 & 126,90 & 3,78 & 2,48 \\
Pendidikan, Rekreasi, dan Olah Raga & 110,55 & 114,73 & 117,57 & 3,78 & 0,74 \\
Transportasi dan Komunikasi & 117,49 & 115,41 & 116,26 & $-1,77$ & 2,64 \\
- BPPBM & 110,76 & 113,21 & 116,20 & 2,21 & 1,70 \\
Bibit & 108,76 & 110,90 & 112,79 & 1,97 & 2,93 \\
Pupuk, Obat-obatan, dan Pakan & 108,83 & 111,57 & 114,84 & 2,52 & 1,48 \\
Biaya Sewa dan Pengeluaran Lain & 109,79 & 111,62 & 113,27 & 1,67 & 0,19 \\
Transportasi & 126,12 & 121,59 & 121,82 & $-3,59$ & 4,28 \\
Penambahan Barang Modal & 112,03 & 115,61 & 120,56 & 3,20 & 3,84 \\
Upah Buruh & 109,03 & 112,73 & 117,06 & 3,39 & \\
\hline Sum & & & & & \\
\hline
\end{tabular}

Sumber: BPS Provinsi Bali, 2017 (diolah)

\section{KESIMPULAN DAN SARAN}

\section{Kesimpulan}

Berdasarkan penelitian yang telah dilakukan, maka dapat disimpulkan sebagai berikut:

1. Nilai tukar petani dari kelima subsektor pertanian tahun 2015-2017 hanya subsektor tanaman panganyang lebih rendah dari tahun dasar (tahun 2012) yang berarti daya beli petani tanaman pangan berada di bawah baya beli pada tahun dasar 2012. Komonen indeks yang mempengaruhi NTP subsektor tanaman pangan yaitu komponen indeks yg diterima (It) dan indeks yang dibayar petani (Ib) berada di atas tahun dasar 2012. Peningkatan nilai tertinggi terjadi pada indeks yang diterima petani palawija yaitu sebesar 11,54 persen. Nilai tukar petani subsektor hortikultura tahun 2015 tidak jauh berbeda dengan tanaman pangan yang juga berada di bawah tahun dasar 2012, yakni sebesar 99,97. Sedangkan subsektor hortikultura tahun 2016-2017 di atas tahun dasar 2012. Sementara itu nilai tukar petani subsektor perkebunan, peternakan dan perikanan berapa pada posisi di atas tahun dasar 2012 atau nilai tukar petani lebih dari
100. NTP tertinggi terjadi pada subsektor peternakan masing-masing tahun 2015 sebesar 113,38, tahun 2016 sebesar 115,20 dan tahun 2017 sebesar 114,23 . Sedangkan peningkatan persentase perubahan komponen indeks NTP 2015 - 2017 tertinggi terjadi pada indeks harga yang diterima petani komoditas sayursayuran subsektor hortikultura sebesar 16,18 persen, disusul berikutnya tanaman perkebunan rakyat sebesar 11,72 persen. Penurunan persentase perubahan komponen indeks NTP 2015 - 2017 terendah terjadi pada indeks harga yang diterima petani komoditas tanaman obat subsektor hortikultura sebesar 4,70 persen, disusul komoditas ternak kecil subsektor peternakan sebesar 0,80 persen.

2. Nilai NTP gabungan dari kelima subsektor dari tahun 2015 - 2017 masing-masing sebesar 104,20 tahun 2015, 106,19 tahun 2016, 104,69 tahun 2017. Secara rata-rata angka NTP gabungan tersebut mencapai 105,03. Sedangkan secara persentase perubahan NTP gabungan tahun 2015 - 2017 naik 0,47 persen. Nilai NTP gabungan tersebut dipengaruhi oleh besaran nilai persentase perubahan dari masing-masing subsektor. Subsektor tanaman perkebunan 
rakyat mengalami kenaikan tertinggi yakni mencapai 4,54 persen dan subsektor tanaman pangan mengalami penurunan terendah yang mencapai 1,89 persen. Hasil NTP yang dirinci menurut bulanan, trend NTP tahun 2016 berada paling atas dan secara garis besar meningkat.

3. Nilai komponen indeks yang diterima petani (It) tahun 2015 - 2017 meningkat. Peningkatan tersebut masing-masing tahun 2015 sebesar 121,73, tahun 2016 sebesar 128,51 dan tahun 2017 sebesar 130,23. Peningkatan indeks yang diterima petani (It) secara persentase naik 5,57 pesen tahun 2015 ke 2016 dan dan 1,34 persen tahun 2016 ke 2017. Sedangkan dari sisi indeks yang dibayar petani (Ib) juga mengalami kenaikan pada tahun 2015 - 2016 sebesar 4,03 persen dan tahun 2016 - 2017 sebesar 2,36 pesen. Komponen indeks yang dibayar petani tersebut terdapat dua kelompokyang mempengaruhi yaitu kelompok konsumsi rumah tangga dan kelompok Biaya Produksi dan Penambahan Barang Modal (BPPBM), masing-masing mengalami kenaikan di tahun 2015 - 2016 sebesar 4,81 persen persen dan 2,21 persen, sedangkan pada tahun 2016 2017 naik 2,42 persen dan 2,64 persen.

\section{Saran}

Peningkatan kesejahteraan petani ditunjukkan melalui daya beli petani yang tercermin dalam nilai tukar petani (NTP). NTP Bali menurut subsektor secara garis besar diatas tahun dasar 2012, kecuali subsektor tanaman pangan. Untuk menaikan NTP tanaman pangan kiranya pemerintah dapat menetapkan harga dasar hasil dari produksi hasil pertanian. Kebijakan harga dasar yang sepadan dengan laju inflasi perdesaan diharapkan mampu meningkatkan daya beli petani untuk memenuhi kebutuhan sehari-hari dapat terpenuhi terutama pada subsektor tanaman pangan. Kondisi demikian berkaitan dengan system penjualan dan penyimpanan hasil produksi pertanian.

Pesentase nilai perubahan NTP bulanan cukup fluktuatif antara 2015 - 2017. Kondisi ini memberikan gambaran pentingnya kestabilan harga tiap komoditas pertanian. Kebijakan pemerintah dibidang pertanian kiranya terus dievaluasi dan ditingkatkan hingga berkelanjutan. Upaya tersebut senantiasa untuk meningkatkan produktivitas hasil pertanian dan pengendalian harga dasar ditingkat petani, sehingga diharapakan mampu meningkatkan kesejahteraan petani.

Pada sistem penghitungan NTP terdapat komponen yang mempengaruhi terhitungan tersebut, indeks yang harus dibayar petani yang terbagi menjadi dua kelompok, yakni konsumsi rumah tangga dan BPPBM. Hasil analisis menunjukkan tingginya biaya yang dibebankan terhadap petani dari kelompok biaya produksi. Kondisi demikian diharapkan menjadi perhatian pemerintah agar kiranya dapat diupayakan dalam membantu dari sisi biaya produksi. Pemerintah dapat membuat program bantuan subsidi bibit, pupuk, obat-obatan maupun pertisida atau alat pengolahan pertanian. Dengan berkurangnya beban biaya produksi, diharapkan mampu meningkatkan margin usaha pertanian dan meningkatkan nilai tukar petani.

\section{DAFTAR PUSTAKA}

BPS. 2013. Laporan Hasil Sensus Pertanian 2013. Badan Pusat Statistik Provinsi Bali.

BPS. 2014. Analisis Sosial Ekonomi Petani di Provinsi Bali Analisis Hasil Survei Pedapatan Petani Sensus Pertanian 2013. Badan Pusat Statistik Provinsi Bali.

BPS. 2014. Pedoman Pencacahan Nilai Tukar Petani (NTP) Dengan Metode Nilai Produksi (NP). Badan Pusat Statistik.

BPS. 2014. Potensi Pertanian Provinsi Bali Analisis Pendataan Lengkap Sensus Pertanian 2013. Badan Pusat Statistik Provinsi Bali.

BPS. 2017. Berita Resmi Statistik [online] https://bali.bps.go.id/webbeta/website/brs_in d/brsInd-20171002143647.pdf (diakses tanggal 2 Oktober 2017).

BPS. 2017. Berita Resmi Statistik [online] https://bali.bps.go.id/webbeta/website/brs_in d/brsInd-20170717160721.pdf (diakses tanggal 2 Oktober 2017).

BPS. 2017. Pedoman Pencacahan Konsumsi Survei Penyempurnaan Diagram Timbang Nilai Tukar Petani (SPDT-NTP) 2017. Badan Pusat Statistik

Dinas Pertanian Dan Tanaman Pangan. 2016. Analisis Sarana Produksi Padi Dan Palawija Provinsi Bali 2015. Dinas Pertanian Dan Tanaman Pangan Provinsi Bali.

Nurasa, Tjetjep. Rahmat, Muchjidin. 2013. Nilai Tukar Petani Padi Di Beberapa Sentra Produksi Padi Di Indonesia. Jurnal Agro Ekonomi: Vol 31, No 2 (2013), Hal 161179.

Rahmat, Muchjidin. 2013. Nilai Tukar Petani :Konsep, Pengukuran Dan, Relevansinya Sebagai Indikator Kesejahteraan Petani. Pusat Penelitian Sosial Ekonomi dan Kebijakan Pertanian. Kementerian Pertanian. Bogor 
Rahmat, Muchjidin. Nuryanti, Sri. 2015. Nilai Tukar Usaha Tani Palawija : Jagung, Kedelai, Dan Ubi Kayu. Pusat Penelitian Sosial Ekonomi dan Kebijakan Pertanian. Kementerian Pertanian. Bogor

Simatupang, P, M. Maulana, 2007. Kaji Ulang Konsep Nilai Tukar Petani Tahun 20032006. Makalah Seminar pada Pusat Analisis Dan Kebijakan Pertanian, Oktober 2006. Bogor.

Sari, Dian Komala. Haryono, Dwi. Rosanti, Novi. 2014. Analisis Pendapatan Dan Tingkat Kesejahteraan Rumah Tangga Petani Jagung Di Kecamatan Natar Kabupaten Lampung Selatan. Jurnal Agro Ekonomi. JIIA, Volume 2, No. 2, Januari 2014. Hal 64-70

Sudaryono. 2017. Metodologi Penelitian. Depok. Raja Grafinso Persada. 